\title{
Physical Properties of Mixed Conductor Solid Oxide Fuel Cell Anodes of Doped CeO2
}

\author{
Mogensen, Mogens Bjerg; Lindegaard, Thomas; Hansen, Uffe Rud; Mogensen, Gurli
}

Published in:

Journal of The Electrochemical Society

Link to article, DOI:

$10.1149 / 1.2055072$

Publication date:

1994

Document Version

Publisher's PDF, also known as Version of record

Link back to DTU Orbit

Citation (APA):

Mogensen, M. B., Lindegaard, T., Hansen, U. R., \& Mogensen, G. (1994). Physical Properties of Mixed

Conductor Solid Oxide Fuel Cell Anodes of Doped $\mathrm{CeO}_{2}$. Journal of The Electrochemical Society, 141(8), 21222128. https://doi.org/10.1149/1.2055072

\section{General rights}

Copyright and moral rights for the publications made accessible in the public portal are retained by the authors and/or other copyright owners and it is a condition of accessing publications that users recognise and abide by the legal requirements associated with these rights.

- Users may download and print one copy of any publication from the public portal for the purpose of private study or research.

- You may not further distribute the material or use it for any profit-making activity or commercial gain

- You may freely distribute the URL identifying the publication in the public portal 


\title{
Physical Properties of Mixed Conductor Solid Oxide Fuel Cell Anodes of Doped $\mathrm{CeO}_{2}$
}

\author{
Mogens Mogensen," Thomas Lindegaard, and Uffe Rud Hansen \\ Risø National Laboratory, Materials Department, DK-4000 Roskilde, Denmark
}

\author{
Gurli Mogensen
}

Haldor Topsøe A/S, DK-2800 Lyngby, Denmark

\begin{abstract}
Samples of $\mathrm{CeO}_{2}$ doped with oxides such as $\mathrm{CaO}$ and $\mathrm{Gd}_{2} \mathrm{O}_{3}$ were prepared. Their conductivities and expansions on reduction were measured at $1000^{\circ} \mathrm{C}$, and the thermal expansion coefficients in the range 50 to $1000^{\circ} \mathrm{C}$ were determined. The ionic and electronic conductivity were derived from curves of total conductivity $v s$. oxygen partial pressure. For both types of conductivity a dependence on dopant valency was observed. The electronic conductivity was independent of dopant radius in contrast to the ionic which was highly dependent. These measured physical properties are compared with the ideal requirements for solid oxide fuel cell anodes. Not all requirements are fulfilled. Measures to compensate for this are discussed.
\end{abstract}

Mixed ionic and electronic conductors (MIEC) seem to be the best type of electrode materials for electrochemical devices such as solid oxide fuel cells (SOFC) and electrolyzers. However, until now most developers of SOFC do not use effective MIEC electrodes. The reason for this is that it is not sufficient for a material to be an MIEC. For an MIEC to act as both an efficient electrode and current collector several requirements must be fulfilled: $(i)$ ionic conductivity, $\sigma_{\mathrm{i}} \geq 0.1 \mathrm{~S} / \mathrm{cm}$ and electronic conductivity, $\sigma_{\mathrm{e}} \geq 100 \mathrm{~S} / \mathrm{cm}$ at operating conditions; (ii) dimensional and thermodynamic stability over wide ranges of oxygen partial pressure and temperature; (iii) good thermal expansion coefficient match with the electrolyte; (iv) chemical compatibility with the electrolyte during operation and fabrication; and (v) high electrocatalytic activity for oxygen reduction and fuel oxidation for cathode and anode, respectively.

Ceramics based on $\mathrm{CeO}_{2}$ exhibit qualities which to a great extent meet the requirements of an SOFC anode fueled with $\mathrm{CH}_{4}+3 \% \mathrm{H}_{2} \mathrm{O}$ (methane saturated with water at $25^{\circ} \mathrm{C}$ ). ${ }^{1-3}$ This is attributed particularly to the mixed $\mathrm{O}^{2-}$ and $e^{-}$conductivity introduced by the large departure from stoichiometry realized in $\mathrm{CeO}_{2}$ at high temperatures in reducing atmosphere. The higher these two conductivities are, the better the $\mathrm{CeO}_{2}$-based electrode may be. The ionic conductivity is increased by orders of magnitude when oxide ion vacancies are formed as a consequence of doping with lower valent cations. Such doping however, may cause a considerable decrease in the electronic conductivity, which makes it important to find a suitable dopant giving a good combined $e^{-}$and $\mathrm{O}^{2-}$ conductivity.

A problem associated with $\mathrm{CeO}_{2}$ is a large expansion and contraction which is observed during reduction and oxidation, respectively. The consequence is formation of cracks at the electrode/electrolyte interface and eventually detachment of the electrode. This problem may be reduced significantly by suitable doping. ${ }^{4}$

Even though doped $\mathrm{CeO}_{2}$ has been studied extensively (see e.g. Ref. 5-10 and references therein), consistent data sets from the literature may be derived only for ionic conductivity, and at $1000^{\circ} \mathrm{C}$ it is not possible to get a clear picture of the importance of the grain boundary resistance. The literature contains clear discrepancies about electronic conductivity, and only limited data are available on thermal expansion and on the dimensional change as a function of oxygen partial pressure, $p_{\mathrm{O}_{2}}$. Therefore, experimental work was undertaken with the aim of creating a basis for optimizing ceria-based anode.

* Electrochemical Society Active Member.

\section{Experimental}

Pure $\mathrm{CeO}_{2}$ samples were prepared by uniaxial pressing of commercial powder (REACTON $99.9 \% \mathrm{CeO}_{2}$, the impurities being mainly other rare earths). $\mathrm{CeO}_{2}$ samples doped with $\mathrm{Gd}_{2} \mathrm{O}_{3}, \mathrm{Sm}_{2} \mathrm{O}_{3}, \mathrm{Y}_{2} \mathrm{O}_{3}, \mathrm{CaO}, \mathrm{Pr}_{2} \mathrm{O}_{3}, \mathrm{Sc}_{2} \mathrm{O}_{3}$, etc. were prepared from $\mathrm{Ce}\left(\mathrm{NO}_{3}\right)_{3} \cdot 6 \mathrm{H}_{2} \mathrm{O}, \mathrm{Gd}\left(\mathrm{CH}_{3} \mathrm{COO}\right)_{3}, \mathrm{Sm}\left(\mathrm{NO}_{3}\right)_{3}$, $\mathrm{Y}\left(\mathrm{CH}_{3} \mathrm{COO}\right)_{3}, \mathrm{Ca}\left(\mathrm{NO}_{3}\right)_{2}, \operatorname{Pr}\left(\mathrm{NO}_{3}\right)_{3}$, or $\mathrm{Sc}\left(\mathrm{CH}_{3} \mathrm{COO}\right)_{3}$ by a process similar to that of Pechini. ${ }^{11}$ The purity of the $\mathrm{Ce}\left(\mathrm{NO}_{3}\right)_{3}$. $6 \mathrm{H}_{2} \mathrm{O}$ was better than $98.5 \%$ and of other salts better than $99.9 \%$. In the cerium compound the impurities were stated to be mainly other rare earths ( $\mathrm{La}<0.2 \%, \mathrm{Er}<0.2 \%$, others $<0.04 \%$ ). The level of impurities such as $\mathrm{Fe}$ and $\mathrm{Pb}$ were below $20 \mathrm{ppm}$. The sample doped with $\mathrm{V}_{2} \mathrm{O}_{5}$ was prepared directly from the oxides by a solid-state reaction route. All samples prepared according to the Pechini method plus the pure $\mathrm{CeO}_{2}$ were sintered at $1600^{\circ} \mathrm{C}$ for $2 \mathrm{~h}$, the rest were sintered at $1600^{\circ} \mathrm{C}$ for $12 \mathrm{~h}$. All samples had densities close to $90 \%$ of the theoretical value except the pure ceria $(74 \%)$. In all cases the measured conductivities were corrected for the porosity by dividing with the actual density and multiplying with the theoretical.

This correction procedure probably gives values slightly too low. It was chosen in spite of this for two reasons; (i) most of the literature data available for comparison are stated to be corrected this way and (ii) to make a theoretically well-founded correction we must make a careful characterization of the porosity structure. This takes a major effort and probably only changes the conductivity values by a few percent. Brugner and Blumenthal ${ }^{12}$ reported a comparison of conductivity values for a singlecrystal $\mathrm{CeO}_{2}$ and sintered $\mathrm{CeO}_{2}$ samples 70 and $85 \%$ dense, and found excellent agreement using this simple correction procedure.

The samples were examined by $\mathrm{x}$-ray diffraction (XRD) and with one exception consisted of a single-phase fluorite structure. Traces of undissolved $\mathrm{Sc}_{2} \mathrm{O}_{3}$ were detected in the compound with the nominal formula $\mathrm{Ce}_{0.905} \mathrm{Sc}_{0.095} \mathrm{O}_{1.953}$.

The conductivity measurements were carried out in a furnace where the oxygen partial pressure was controlled by well-defined mixtures of air, $\mathrm{Ar}, \mathrm{CO}_{2}, \mathrm{CO}, \mathrm{H}_{2} \mathrm{O}$, and $\mathrm{H}_{2}$. In all cases the oxygen potential was measured with an oxygen sensor and showed good agreement with values derived from thermodynamic data. The measurements were performed using a two-electrode setup and a computer-controlled Solartron 1260 impedance analyzer similar to the procedure described by Bentzen et $a l .{ }^{13}$ The resistances of the leads were measured frequently by shortcircuiting the sample holder. The resistances of leads were in the range of 3.8 to $4.2 \Omega$. Changes in this resistance were observed only after occasional replacement of leads or electrodes. The uncertainty of the measured resistances of the 


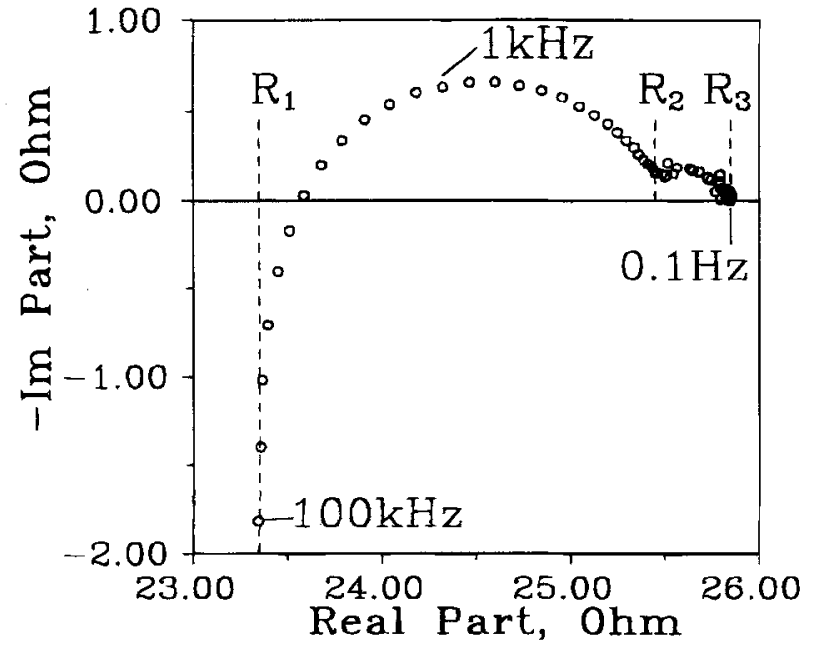

Fig. 1. A raw impedance plot for the sample $\mathrm{Ce}_{0.8} \mathrm{Ca}_{0.2} \mathrm{O}_{1.8}$ measured in air at $1000^{\circ} \mathrm{C}$. $R_{1}$ is equal to the sample lattice resistance plus the lead resistance. $R_{2}-R_{1}$ is the grain boundary resistance, and $R_{3}-R_{2}$ is the electrode resistance. The lead resistance is measured in a separate experiment.

samples were $0.05 \Omega$ resulting in a maximum uncertainty of $5 \%$ for the specific conductivity. The temperature was measured in all cases to $1000 \pm 3^{\circ} \mathrm{C}$.

The measurements on expansion on reductions and of the thermal expansion coefficients were performed according to previously described procedures. ${ }^{4}$

\section{Results and Discussion}

The measured impedances were plotted in the complex plane and the contributions from lattice, grain boundaries, and electrodes were separated using LEVM which is a PCbased fitting program developed by Macdonald. ${ }^{14}$

Examples of impedance plots for the sample $\mathrm{Ce}_{0.8} \mathrm{Ca}_{0.2} \mathrm{O}_{1.8}$ obtained at different $p_{\mathrm{O}_{2}}$ are given in Fig. 1, 2, and 3. The vertical part below the real axis in all the plots is due to inductive elements in the experimental setup. Figure 1 shows an impedance spectrum measured in air. How the response is separated into contributions from lattice, grain boundaries, and electrodes is indicated. The conductivity measured in air is assumed to be entirely ionic. The spectrum in Fig. 2 is measured while the sample was exposed to an atmosphere of $\mathrm{CO}$ and $\mathrm{CO}_{2}, p_{\mathrm{O}_{2}}=4.5 \cdot 10^{-11} \mathrm{~atm}$. Besides the inductance Fig. 2 shows only a Warburg type of electrode response. This means that the grain boundary resistance becomes insignificant when the atmosphere is sufficiently reducing. This is attributed to the introduction of electronic carriers short-circuiting the grain boundaries. Also, this electronic conductivity decreases the lattice resistance as revealed by comparing $R_{1}$ of Fig, 2 with $R_{1}$ of Fig. 1. In Fig. 3 the atmosphere is $\mathrm{H}_{2}+3 \% \mathrm{H}_{2} \mathrm{O}, p_{\mathrm{O}_{2}}=4$. $10^{-18} \mathrm{~atm}$. In this case substantial electronic conductivity is introduced and the impedance spectrum is reduced to a single dot; no capacitive elements are observed and no change in the real part is observed when varying the frequency from $100 \mathrm{kHz}$ to $0.1 \mathrm{~Hz}$. This is better illustrated by the Bode plot in Fig. 4 where both real part and imaginary part are given as a function of logarithm of frequency.

All the conductivities reported from this work are lattice conductivities, which supposedly are material properties unaffected by the preparation route. The literature data given, however, are total conductivities including the grain boundary resistance because pure lattice conductivity data at $1000^{\circ} \mathrm{C}$ are not reported. In this work all measured grain boundary resistances were less than $10 \%$ of the total resistance. They are not reported because the values were not revealing any clear trends. It has been reported that grain boundary resistance in fluorite oxides ion conductors in general is dependent on grain size, porosity, and trace impurities. ${ }^{15} \mathrm{~A}$ careful control of these parameters was not attempted here.
Total conductivity.-Using the Kröger Vink notation the reduction of $\mathrm{CeO}_{2}$ may be written as

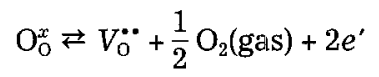

$\mathrm{O}_{\mathrm{O}}^{x}$ is an $\mathrm{O}^{2-}$ ion on its normal site in the $\mathrm{CeO}_{2}$ lattice (regarded as neutral) and $V_{0}^{*}$ is a double positively charged vacancy.

The electronic conductivity is induced when the material is reduced as given in Eq. 1. Additional oxygen is removed from the material when dopants of valence lower than +4 are incorporated in the lattice. This happens according to Eq. 2

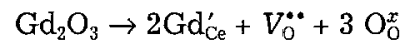

The vacancies that are formed as a consequence of the doping shift the reaction in Eq. 1 to the left, with a decrease in electron concentration and $\sigma_{e}$ as the result.

An overview of the differences between $\mathrm{Gd}_{2} \mathrm{O}_{3}$ and $\mathrm{CaO}-$ doped $\mathrm{CeO}_{2}$ is given in Fig. 5, 6, and 7. Figure 5 shows the total conductivity vs. - $\log p_{\mathrm{O}_{2}}$ for different levels of gadolinia doping. At high $p_{\mathrm{O}_{2}}$ (oxygen partial pressure) the conductivity is only slightly affected by changes in $p_{\mathrm{O}_{2}}$. Under more reducing conditions the conductivity increases and eventually becomes constant or goes through a maxi-

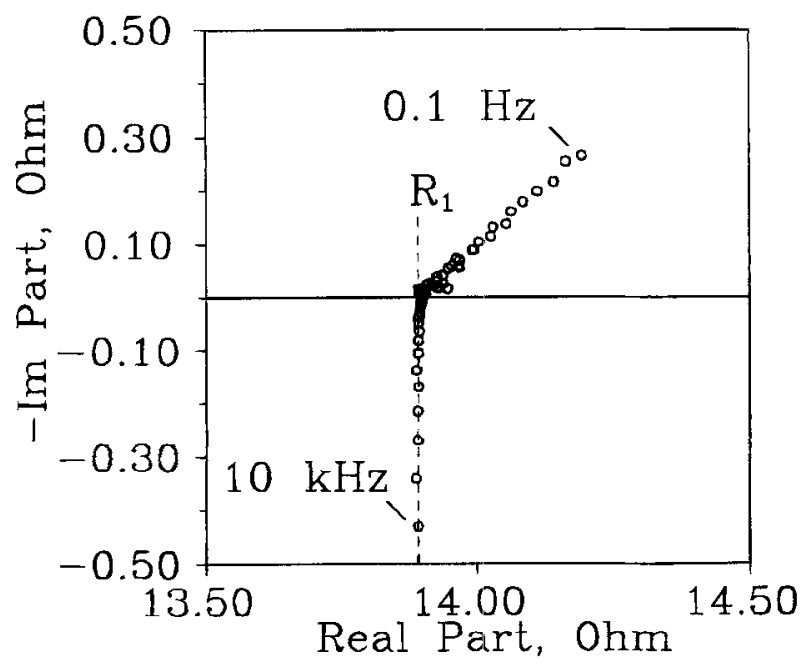

Fig. 2. Impedance plot for the sample of Fig. 1 measured in $\mathrm{CO} /$ $\mathrm{CO}_{2}, \mathrm{PO}_{2}=4.5 \cdot 10^{-11} \mathrm{~atm} 1000^{\circ} \mathrm{C}$.

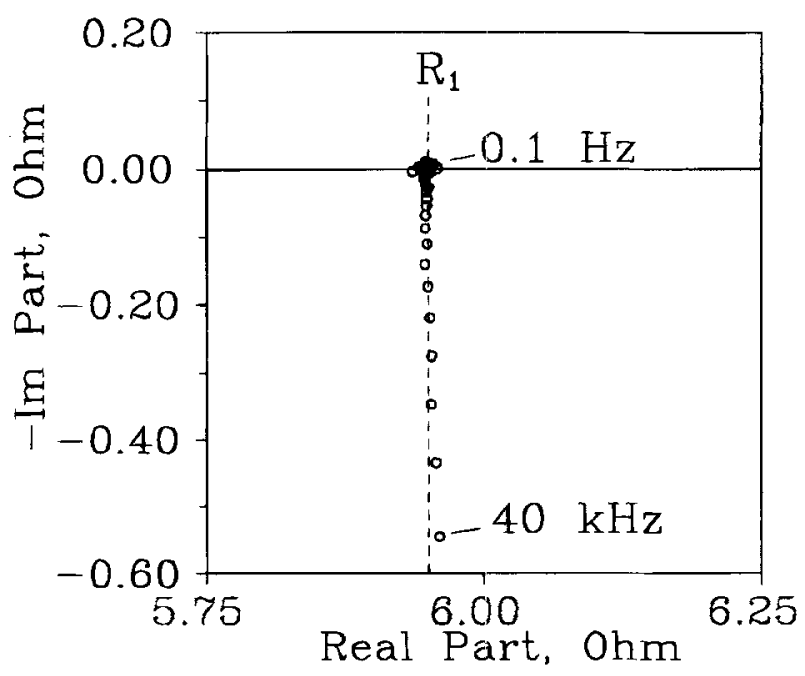

Fig. 3. Impedance plot for the sample of Fig. 1 measured in $\mathrm{H}_{2}+$ $3 \% \mathrm{H}_{2} \mathrm{O}, \mathrm{PO}_{2}=4 \cdot 10^{-18} \mathrm{~atm} 1000^{\circ} \mathrm{C}$. 


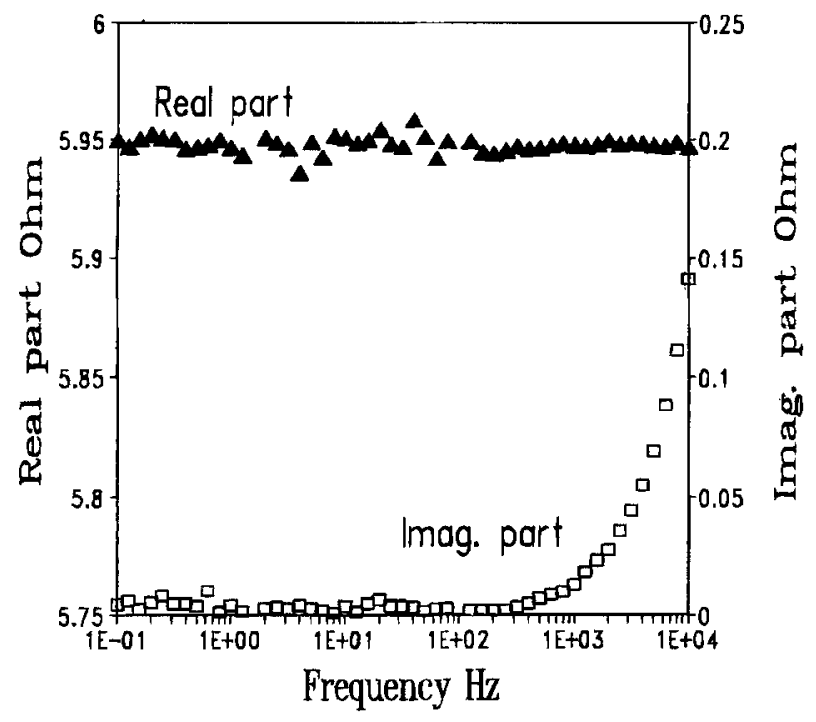

Fig. 4. Bode plot showing real and imaginary part vs. log frequency. The data are the same as in Fig. 3 .

mum. When the dopant concentration is increased the resistance to reduction increases. The result of this is a shift toward lower $p_{\mathrm{O}_{2}}$ values for the same conductivity.

Figure 6 shows the total lattice conductivity vs. - $\log$ $p_{\mathrm{O}_{2}}$ for samples with composition $\mathrm{Ce}_{0.8} \mathrm{Gd}_{0.2} \mathrm{O}_{1.9}$ and $\mathrm{Ce}_{0.9} \mathrm{Ca}_{0.1} \mathrm{O}_{1.9} \cdot \mathrm{Ce}_{0.8} \mathrm{Gd}_{0.2} \mathrm{O}_{1.9}$ has a slightly higher ionic conductivity, but a significantly lower electronic conductivity.

Figure 7 shows the total lattice conductivity $v s$. - log $p_{\mathrm{O}_{2}}$ for samples with composition $\mathrm{Ce}_{0.6} \mathrm{Gd}_{0.4} \mathrm{O}_{1.8}$ and $\mathrm{Ce}_{0.8} \mathrm{Ca}_{0.2} \mathrm{O}_{1.8}$. The difference in electronic conductivity has been further increased compared to the results in Fig. 6 and the ionic conductivity of the calcia-doped sample is now clearly highest.

Ionic conductivity in air.-For all samples including pure $\mathrm{CeO}_{2}$, the conductivity measured in air is regarded as being ionic, the electronic conductivity contribution being negligible. This is assumed to be a reasonable approximation as the impedance plots clearly showed the presence of semiarcs indicating that the capacitance of the grain boundaries was not short-circuited. All ionic conductivities reported in the following are lattice conductivities obtained from measurements performed in air.

The ionic lattice conductivity, $\sigma_{i, 1}$, at $1000^{\circ} \mathrm{C}$ for $\mathrm{CeO}_{2}$ doped with either $\mathrm{Gd}_{2} \mathrm{O}_{3}$ or $\mathrm{CaO}$ is shown in Fig. 8. $\sigma_{i, 1}$ is plotted as a function of the nominal vacancy concentration, $\left[V_{0}^{* *}\right]$, which is the concentration of vacancies necessary to obtain electrical neutrality in the lattice, assuming unassociated double-charged vacancies.

Five different concentrations of $\mathrm{Gd}_{2} \mathrm{O}_{3}$ have been investigated including pure $\mathrm{CeO}_{2}$. The highest ionic conductivity found was $0.21 \mathrm{~S} \cdot \mathrm{cm}^{-1}$, which was measured for the compound $\mathrm{Ce}_{0.8} \mathrm{Gd}_{0.2} \mathrm{O}_{1.9}$. This is in reasonable agreement with literature data ${ }^{16}$ regarding the concentration as well as the conductivity. As the literature data include grain boundary resistance it indicates that the grain boundary resistance is relatively low in all cases at $1000^{\circ} \mathrm{C}$. The values measured within this work also confirm literature data on other dopant concentrations $[4,6,8$, and 40 atom percent $(\mathrm{a} / \mathrm{o})]$. $^{16-1 \overline{8}}$

Doping with $\mathrm{CaO}$ gives lower values of $\sigma_{i, 1}$ than $\mathrm{Gd}_{2} \mathrm{O}_{3}$ in the concentration range from 0 to $10 \mathrm{a} / \mathrm{o} \mathrm{Ca}$. The maximum $\sigma_{i, 1}$ was $0.19 \mathrm{~S} / \mathrm{cm}$, measured for $\mathrm{Ce}_{0.9} \mathrm{Ca}_{0.1} \mathrm{O}_{1.9}$. The values obtained here are, with one exception, very close to the results of Blumenthal et al. ${ }^{19}$ and Arai et al. ${ }^{20}$ The sample doped with $20 \% \mathrm{CaO}$ also had an ionic conductivity of $0.19 \mathrm{~S} \cdot \mathrm{cm}^{-1}$. This is higher than found by Arai et al. $(0.16 \mathrm{~S} / \mathrm{cm}){ }^{20}$

Three main parameters determine the ionic lattice conductivity $\sigma_{i, 1}$ : temperature, dopant concentration (concentration of oxide ion vacancies), and dopant metal ion ra- dius, see e.g. Ref. 15. The assumption of unassociated vacancies is only valid for dilute dopant concentrations, recognized in Fig. 8 as the range with a linear correlation between $\sigma_{i}$ and $\left[V_{0}^{*}\right]$. When the nominal vacancy concentration $\left[V_{0}^{*}\right]$ is increased above 2 to $3 \%$ of oxide lattice sites the curve levels off and goes through a maximum. For gadolinia the maximum is located at $\left[V_{0}^{* *}\right]=5 \%$ corresponding to $20 \mathrm{a} / \mathrm{o} \mathrm{Gd}$. Increasing the dopant concentration above this level causes the formation of defect clusters which make a part of the vacancies less mobile. The maximum ionic conductivity for samples doped with $\mathrm{CaO}$ is obtained at a concentration range above $10 \mathrm{a} / \mathrm{o} \mathrm{Ca},\left[\mathrm{V}_{\mathrm{O}}^{\cdot *}\right]>5 \%$.

The effect of the dopant ionic radius on $\sigma_{i, 1}$ is illustrated in Fig. 9 showing $\sigma_{i, 1} v s . \Delta r . \Delta r$ is defined as the difference between the critical radius, $r_{\mathrm{c}}$, and dopant ionic radius. $r_{\mathrm{c}}$ is defined by $\mathrm{Kim}^{21}$ as the dopant ionic radius which causes no change in the lattice parameters when the dopant oxide is dissolved in the fluorite structure. $r_{\mathrm{c}}=1.106 \AA$ for divalent dopants and $1.038 \AA$ for trivalent dopants (the ionic radius of $\mathrm{Ce}^{+4}$ is $0.97 \AA$ ). ${ }^{22}$ In Fig. 9 results obtained here are presented together with literature data. For all samples $\left[V_{\mathrm{O}}^{*}\right]=2.5 \%$ of the total amount of anion sites in the lattice. The general trend shown in this figure points out that the smaller the difference between the radius of dopant ion and $r_{\mathrm{c}}$ the higher is $\sigma_{\mathrm{i}, 1}$ for a given dopant valency. There is also an indication that the correlation between $\Delta r$ and $\sigma_{i, 1}$ varies

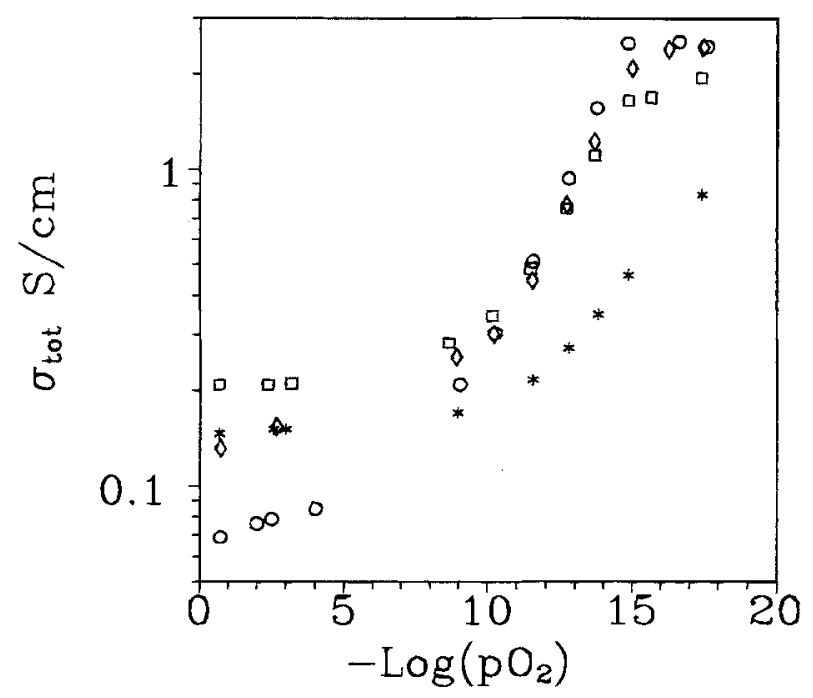

Fig. 5. Total conductivity (ionic + electronic) at $1000^{\circ} \mathrm{C}$ vs. $-\log p_{O_{2}}$ for compounds with the composition $\mathrm{Ce}_{2-x} \mathrm{Gd}_{x} \mathrm{O}_{2-x / 2}$. ( ${ }^{*} X=0.4$, $\square X=0.2, \diamond X=0.0905, \diamond X=0.049)$.

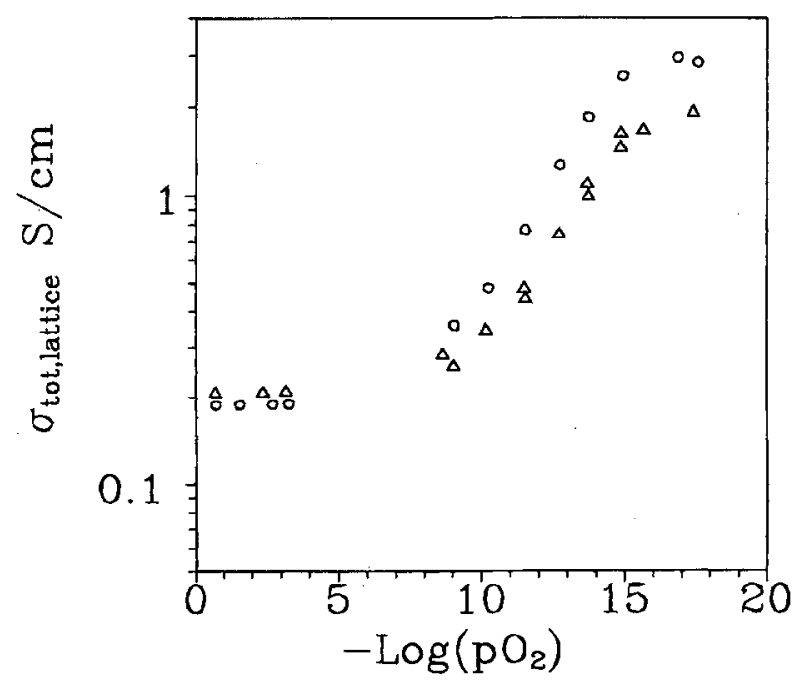

Fig. 6. Total lattice conductivily at $1000^{\circ} \mathrm{C}$ vs. $-\log \mathrm{PO}_{2}$ for $\mathrm{Ce}_{0.8} \mathrm{Gd}_{0.2} \mathrm{O}_{1.9}(\Delta)$ and $\mathrm{Ce}_{0.9} \mathrm{Ca}_{0.1} \mathrm{O}_{1.9}(\mathrm{O})$. 


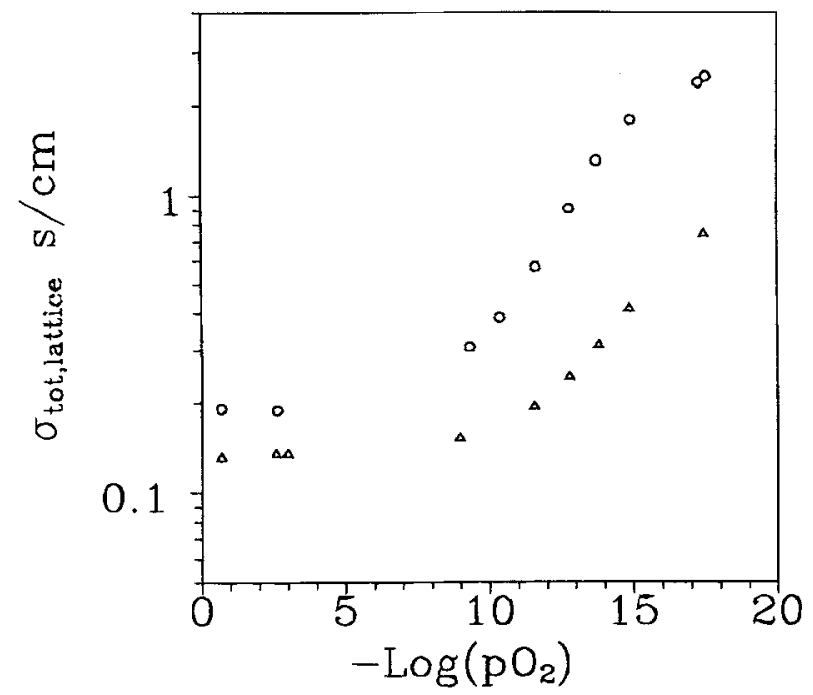

Fig. 7. Total lattice conductivity at $1000^{\circ} \mathrm{C}$ vs. $-\log \mathrm{PO}_{2}$ for $\mathrm{Ce}_{0.6} \mathrm{Gd}_{0.4} \mathrm{O}_{1.8}(\triangle)$ and $\mathrm{Ce}_{0.8} \mathrm{Ca}_{0.2} \mathrm{O}_{1.8}(\mathrm{O})$.

with the valency of the dopant ion. The figure implies that $\sigma_{i, 1}$ is more affected by ion radius of trivalent dopants than by the divalent. The two curves have been drawn to guide the eye, the experimental data are too few to make any definite conclusions on this matter.

The implication of Fig. 9 is that the best trivalent dopant ion is $\mathrm{Tb}^{3+}$ for which $\Delta r$ is only $0.002 \AA$ but only marginally better than $\mathrm{Gd}^{3+}$ with $\Delta r=0.015 \AA$. $\mathrm{Gd}_{2} \mathrm{O}_{3}$ was chosen for the detailed investigation because $\mathrm{Gd}_{2} \mathrm{O}_{3}$ is considerably cheaper than $\mathrm{Tb}_{2} \mathrm{O}_{3}$.

Ionic conductivity in reducing atmosphere.-In the literature ${ }^{15} \sigma_{\mathrm{i}}$ is often regarded as constant, independent of $p_{\mathrm{O}_{2}}$. This however is not fully true. $\mathrm{As}^{\mathrm{CeO}_{2}}$ is reduced according to Eq. 1 the concentration of vacancies is increased which leads to a change in $\sigma_{i}$. The maximum in $\sigma_{i}$ is probably obtained close to $\left[V_{0}^{* *}\right]=5 \%$ of anion sites. Direct measurement of $\sigma_{i}$ has not been possible under reducing conditions, but an estimate has been obtained using the data of Zachau-Christiansen et al. ${ }^{23}$ where the oxygen stoichiometry has been determined for pure and Gd-doped ceria as a function of $p_{\mathrm{O}_{2}}$ using a procedure previously described by Jacobsen et al. ${ }^{24} \sigma_{\mathrm{i}}$ is expected to be affected by the reduction process in the same way as when the concentration of trivalent dopant is increased. In this case the dopant is $\mathrm{Ce}^{3+}$.

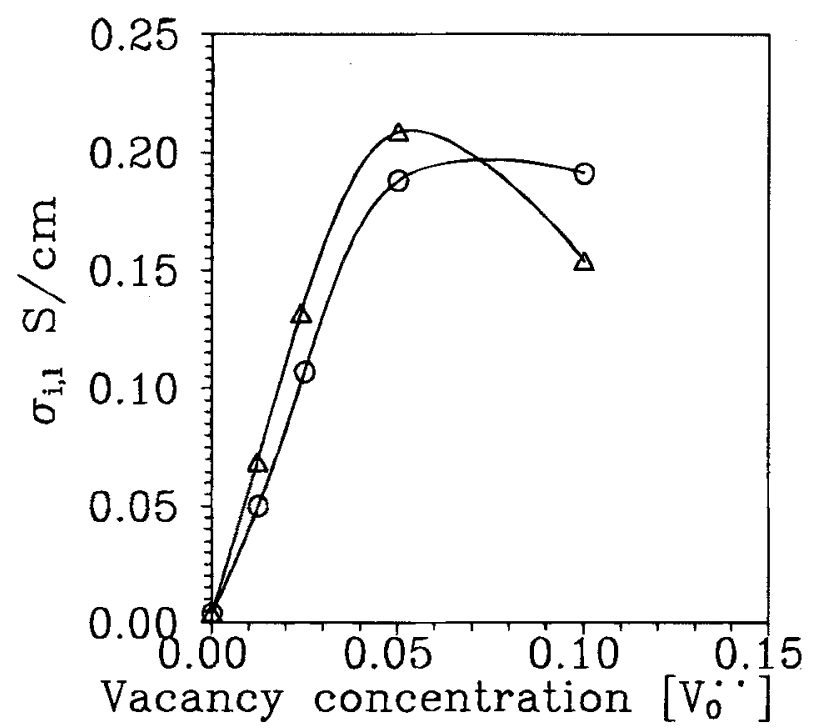

Fig. 8. Ionic conductivity as a function of vacancy concentration (in fraction of O-sites) for samples doped with $\mathrm{Gd}_{2} \mathrm{O}_{3}(\triangle)$ and $\mathrm{CaO}(\mathrm{O})$ at $1000^{\circ} \mathrm{C}$ in air.

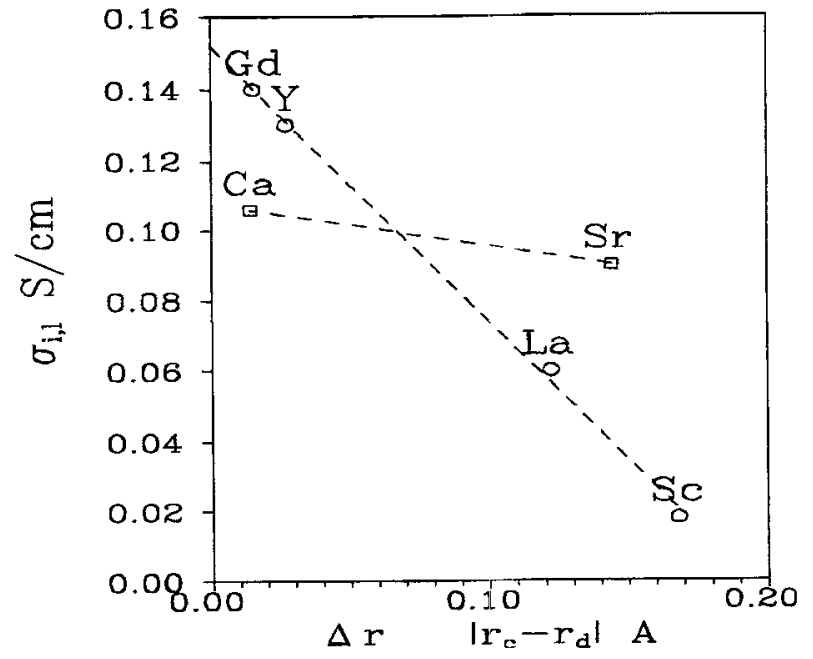

Fig. 9. Ionic conductivity at $1000^{\circ} \mathrm{C}$ vs. $\Delta r$, the difference between dopant ionic radius and $r_{\mathrm{C}}$ as defined by $\mathrm{Kim}^{21} r_{\mathrm{C}}$ is the dopant ionic radius which causes no change in the lattice parameters when the dopant oxide is dissolved in the fluorite structure. The data on $\mathrm{Sr}$ and La doped samples is from Ref. 32 and 16, respectively. The nominal vacancy concentration is $\mathbf{2 . 5 \%}$ of anion sites.

The ionic radius of $\mathrm{Ce}^{3+}$ is close to that of $\mathrm{La}^{3+}$ (1.143 and $1.16 \AA$, respectively). ${ }^{22}$ Knowing that the ionic radius of the dopant material is an important parameter for the value of $\sigma_{i}$ it has been assumed that $\sigma_{i}$ (measured in air) for the compound $\mathrm{Ce}_{1-2 x} \mathrm{La}_{2 x} \mathrm{O}_{2-x}$ is a good estimate for $\sigma_{i}$ in $\mathrm{CeO}_{2-x}$ (alternatively written as $\mathrm{Ce}_{1-2 x}^{4+} \mathrm{Ce}_{2 x}^{3+} \mathrm{O}_{2-x}$ ). Combining the stoichiometry measurements of Zachau-Christiansen ${ }^{23}$ with conductivity measurements on $\mathrm{Ce}_{1-2 x} \mathrm{La}_{2 x} \mathrm{O}_{2-x},{ }^{16}$ a curve showing $\log \left(\sigma_{i}\right) v s$. $-\log p_{\mathrm{O}_{2}}$ for $\mathrm{CeO}_{2-x}$ has been constructed (Fig. 10). The curve goes through a maximum with the highest $\sigma_{1}=0.07 \mathrm{~S} / \mathrm{cm}$ obtained at $p_{\mathrm{O}_{2}}=10^{-16} \mathrm{~atm}$ and $\left[V_{0}^{* *}\right]=5.3 \%$ of anion sites. The maximum $\sigma_{i}$ obtained from Fig. 10 is approximately 18 times higher than $\sigma_{i}$ measured in air, the latter being controlled by the impurity level of lower valent dopants.

In the case of the doped samples the correlation between $\sigma_{\mathrm{i}}$ and $p_{\mathrm{O}_{2}}$ depends on the dopant concentration, e.g., $\mathrm{Ce}_{0.8} \mathrm{Gd}_{0.2} \mathrm{O}_{1.9}$, where the optimum concentration of vacancies already has been achieved, $\sigma_{i}$ probably decreases when $p_{\mathrm{O}_{2}}$ is lowered.

Compared to the electronic conductivity obtained for oxygen partial pressures lower than $10^{-6}$ atm the change in $\sigma_{1}$ caused by reduction is insignificant. For pure $\mathrm{CeO}_{2}$

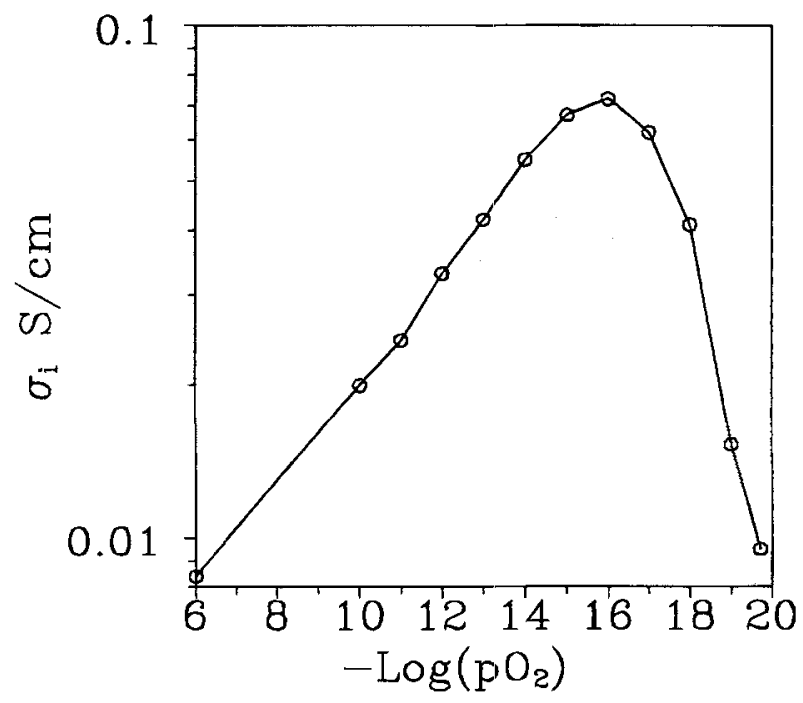

Fig. 10. An estimated curve showing $\log \left(\sigma_{i}\right)$ vs. $-\log \left(p_{\mathrm{O}_{2}}\right)$ for $\mathrm{CeO}_{2-x}$ 


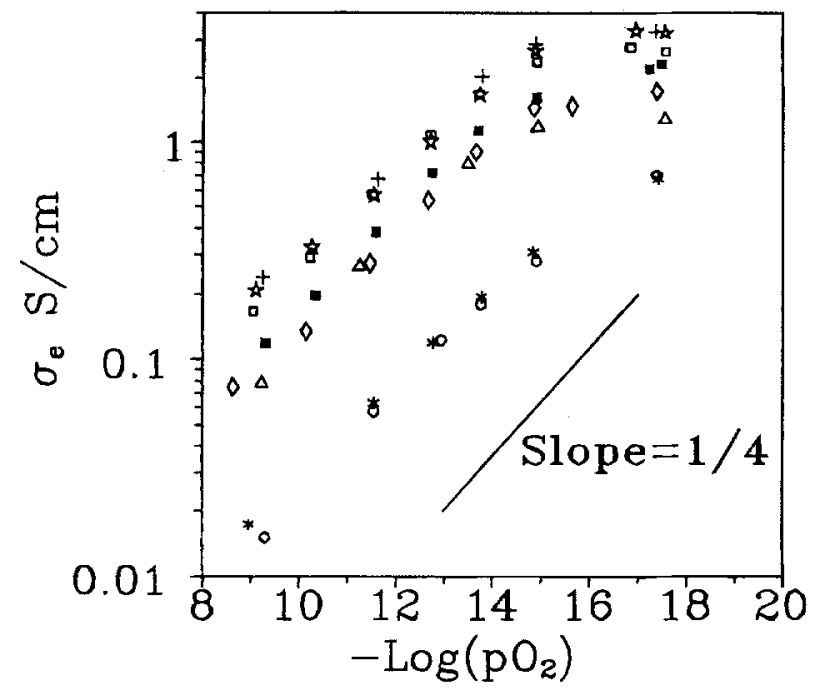

Fig. 11. Electronic conductivily $\sigma_{\mathrm{e}}$ vs. - - $\log p_{\mathrm{o}_{2}}$ for different dopants and dopant concentrations at $1000^{\circ} \mathrm{C}$. $\sigma_{e}$ is calculated from the total conductivity assuming a $\mathrm{P}_{2}$ independent ionic conductivity. 1 . Pure $\mathrm{CeO}_{2},+2 \% \mathrm{~V}, \square 10 \% \mathrm{Ca}, 20 \% \mathrm{Ca}, \diamond 20 \% \mathrm{Gd}, \triangle 20 \% \mathrm{Pr},{ }^{*} 40 \%$ Gd, $\bigcirc 0 \% \mathrm{Sm}$ ).

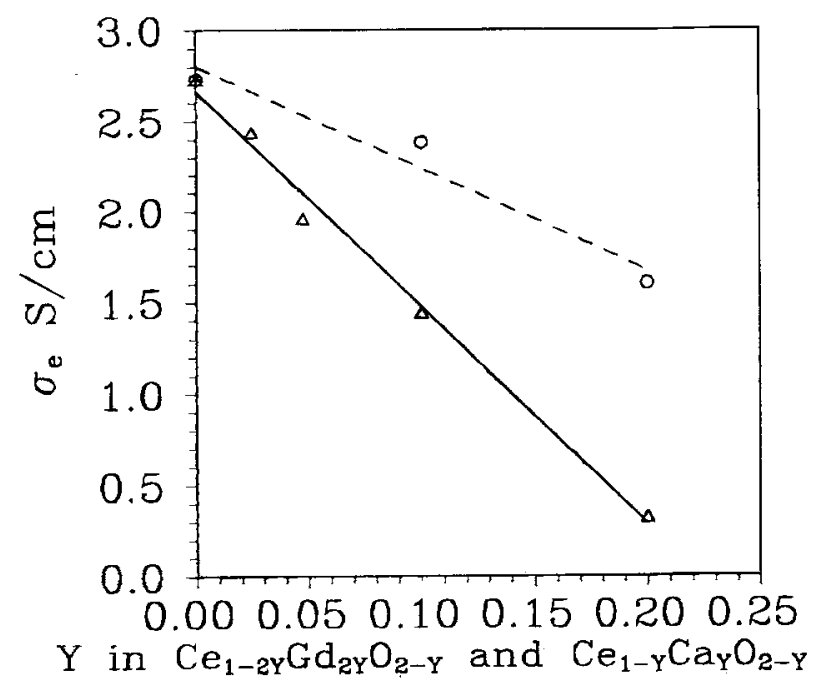

Fig. 12. Electronic conductivity at $p_{\mathrm{O}_{2}}=10^{-15} \mathrm{~atm}$ and $1000^{\circ} \mathrm{C}$ vs. $Y$ in $\mathrm{Ge}_{1-2 y} \mathrm{Gd}_{2 y} \mathrm{O}_{2-y}(\Delta)$ and $\mathrm{Ce}_{1-y} \mathrm{Ca}_{y} \mathrm{O}_{2-y}(O)$.

which has the ionic conductivity most sensitive to changes in $p_{\mathrm{O}_{2}}, \sigma_{\mathrm{i}}$ introduced by the reduction is less than $3 \%$ of the total conductivity at $p_{\mathrm{O}_{2}}=10^{-6} \mathrm{~atm}$. At lower values of $p_{\mathrm{O}_{2}}$ the contribution is even smaller.

Electronic conductivity.-Fundamental studies on the $n$-type conduction in $\mathrm{CeO}_{2-x}$ have been reported in the literature. ${ }^{25-27}$ It is generally agreed that the conduction occurs via a small polaron hopping mechanism, but there is disagreement in the literature about how $\sigma_{\mathrm{e}}$ depends on dopant concentration. Ivers-Tiffée and Küstner ${ }^{10}$ and IversTiffée and $\mathrm{Oel}^{23}$ have examined the electronic conductivity of samples with the composition $\mathrm{Ce}_{1-x} \mathrm{M}_{x} \mathrm{O}_{2-x / 2}(\mathrm{M}=\mathrm{Gd}$, Er, Nd and $x=0$ to 0.16$)$ in the temperature range from 700 to $900^{\circ} \mathrm{C}$, and have found that $\sigma_{e}$ is not affected by any changes in dopant material or concentration. In contradiction to this, El Adham ${ }^{29}$ has found a slope of $\log \sigma_{e} v s . \log x$ to be approximately $-1 / 2$ for $0<x<0.15$ at $793^{\circ} \mathrm{C}$ and $p_{\mathrm{O}_{2}}=1.5$. $10^{-13} \mathrm{~atm}$, i.e., the electronic conductivity decreases with increasing concentration of dopants with valence lower than +4 . The same slope has been obtained here at $1000^{\circ} \mathrm{C}$ and $p_{\mathrm{O}_{2}}=10^{-12} \mathrm{~atm}$ for $0.045<x<0.1$. For values of $x \geq 0.2$ or $p_{\mathrm{O}_{2}} \leq 10^{-13}$ atm other correlations have been found, but in all cases the results of the present work (shown in Fig. 11,
12 , and 13) confirm clearly that $\sigma_{\mathrm{e}}$ decreases when $\mathrm{CeO}_{2}$ is doped with lower valent cations.

Figure 11 shows the electronic conductivity, $\sigma_{\mathrm{e}}, v s .-\log$ $p_{\mathrm{O}_{2}}$ for various dopants in varying concentrations. $\sigma_{\mathrm{e}}$ is simply found as $\sigma_{\text {tot }}-\sigma_{i}$, where $\sigma_{\text {tot }}$ is the total conductivity and $\sigma_{i}$ is the ionic lattice conductivity measured in air. Considering the arguments given in the section Ionic Conductivity in Reducing Atmosphere, this approximation seems reasonable.

For undoped $\mathrm{CeO}_{2}$ it can be shown ${ }^{15}$ that the concentration of electronic charge carriers, $n$, is correlated to $p_{\mathrm{O}_{2}}: n \propto$ $p_{\mathrm{O}_{2}}^{-1 / 6}$ for small departures from stoichiometry, and $n \propto p_{\mathrm{O}_{2}}^{-1 / 4}$ for large departures from stoichiometry. In the case of the doped samples the theoretical correlation is: $n \propto p_{\mathrm{O}_{2}}^{-1 / 4}$.

The curves for the doped samples (Fig. 11) show that the slope is close to the theoretical value 0.25 and that it is virtually unaffected by both the kind of dopant and concentration. For pure $\mathrm{CeO}_{2}$ the slope is approximately 0.2 indicating a transition state between the two theoretical slopes. The observed decrease in conductivity, compared to pure $\mathrm{CeO}_{2}$, is almost the same when doping to equal concentrations of $\mathrm{Gd}_{2} \mathrm{O}_{3}$ and $\mathrm{Pr}_{2} \mathrm{O}_{3}$ or $\mathrm{Gd}_{2} \mathrm{O}_{3}$ and $\mathrm{Sm}_{2} \mathrm{O}_{3}$. It appears that $\sigma_{e}$ is not affected by the choice of dopant as long as the valence of the dopant material remains the same ( +3 in this case). Doping with the divalent $\mathrm{CaO}$ also causes a lowering of $\sigma_{e}$, but not as much as the trivalent lanthanides do.

Doping with the pentavalent $\mathrm{V}_{2} \mathrm{O}_{5}$ shows a slight increase in $\sigma_{\mathrm{e}}$ compared to pure $\mathrm{CeO}_{2}$. This can be attributed to the introduction of cation vacancies. These react with oxide vacancies with the result that Eq. 1 is shifted to the right. The consequence of this is a decrease in $\sigma_{i}$ and an increase in $\sigma_{\mathrm{e}}$. Similar observations have been reported in the literature. ${ }^{30,31}$

Figure 12 and 13 compare $\sigma_{\mathrm{e}}$ at $p_{\mathrm{O}_{2}}=10^{-15}$ atm for samples doped with $\mathrm{Gd}_{2} \mathrm{O}_{3}$ or CaO. In Fig. $12 \sigma_{\mathrm{e}}$ is plotted vs. $y$ in $\mathrm{Ce}_{1-2 y} \mathrm{Gd}_{2 y} \mathrm{O}_{2-y}$ and $\mathrm{Ce}_{1-y} \mathrm{Ca}_{y} \mathrm{O}_{2-y}$, whereas in Fig. $13 \sigma_{\mathrm{e}}$ is plotted vs. the dopant concentration in atom fraction. Figure 12 is shown to compare compounds which have equal nominal concentrations of defects in the anion lattice, e.g., $\mathrm{Ce}_{0.8} \mathrm{Gd}_{0.2} \mathrm{O}_{1.9}$ and $\mathrm{Ce}_{0.9} \mathrm{Ca}_{0.1} \mathrm{O}_{1.9}$. The formulas in Fig. $12 \mathrm{do}$ not represent the true stoichiometry at $p_{\mathrm{O}_{2}}=10^{-15} \mathrm{~atm}$. Due to the reducing atmosphere additional oxygen has been removed from the lattice. To find the exact extent of this reduction we must measure the stoichiometry as in the work of Zachau-Christiansen et al. ${ }^{23}$ or by thermogravimetry. One of the main findings of Ref. 23 is that for a given $p_{\mathrm{O}_{2}}$ value the oxygen stoichiometry, e.g., at $p_{\mathrm{O}_{2}}=10^{-15} \mathrm{~atm}$ is independent of the $\mathrm{Gd}$ concentration up to $40 \mathrm{a} / \mathrm{o} \mathrm{Gd}$. In the $p_{\mathrm{O}_{2}}$ interval from $10^{-14}$ to $10^{-20}$ atm the oxide vacancy con-

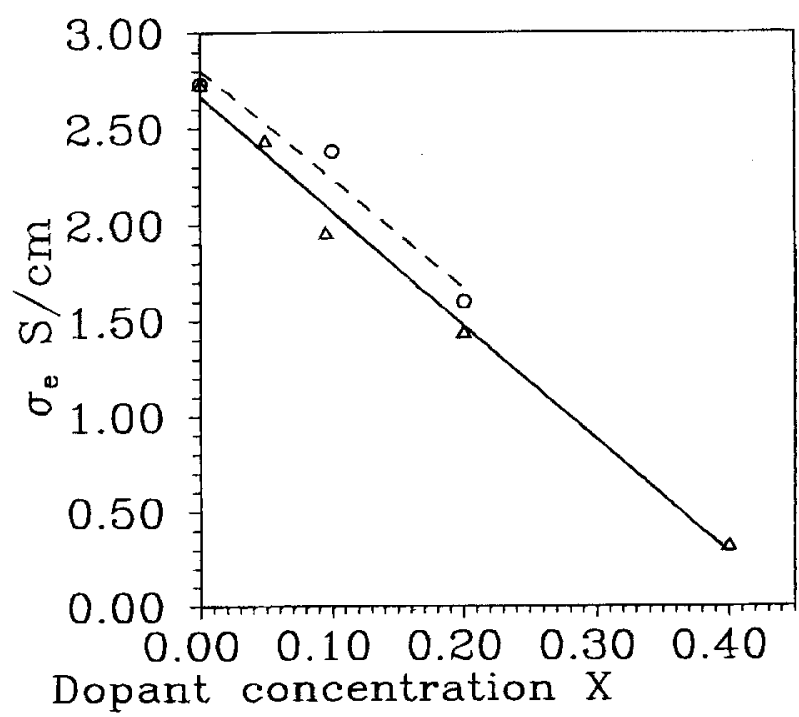

Fig. 13. Electronic conductivity at $p_{\mathrm{O}_{2}}=10^{-15} \mathrm{~atm}$ and $1000^{\circ} \mathrm{C}$ vs. $X$ in $\mathrm{Ce}_{1-x} \mathrm{Gd}_{x} \mathrm{O}_{2-x / 2}(\triangle)$ and $\mathrm{Ce}_{1-x} \mathrm{Ca}_{x} \mathrm{O}_{2-x}(O)$. 
Table I. Electronic conductivite, $\sigma_{e}$ and ionic radii for dopant material.

\begin{tabular}{lccc}
\hline Sample & $\begin{array}{c}\sigma_{\mathrm{e}} \\
\left(\mathrm{S} \cdot \mathrm{cm}^{-1}\right)\end{array}$ & $\begin{array}{c}\text { Ionic radius of dopant } \\
(\AA)^{\mathrm{a}}\end{array}$ & $\begin{array}{c}\Delta r^{\mathrm{b}} \\
(\AA)\end{array}$ \\
\hline $\mathrm{Ce}_{0.8} \mathrm{Pr}_{0.2} \mathrm{O}_{19}$ & 1.2 & 1.126 & 0.088 \\
$\mathrm{Ce}_{0.8} \mathrm{Gd}_{0.2} \mathrm{O}_{1.8}$ & 1.44 & 1.053 & 0.015 \\
$\mathrm{Ce}_{0 .} \mathrm{Ca}_{01} \mathrm{O}_{1.9}$ & 2.38 & 1.120 & 0.014 \\
$\mathrm{Ce}_{06} \mathrm{Sm}_{0.4} \mathrm{O}_{1.8}$ & 0.30 & 1.079 & 0.041 \\
$\mathrm{Ce}_{0.6} \mathrm{Gd}_{0.4} \mathrm{O}_{1.8}$ & 0.33 & 1.053 & 0.015 \\
$\mathrm{Ce}_{0.6} \mathrm{La}_{0.4} \mathrm{O}_{1.8}$ & 0.33 & 1.160 & 0.122 \\
$\mathrm{Ce}_{0.8} \mathrm{Ca}_{0.2} \mathrm{O}_{1.8}$ & 1.6 & 1.12 & 0.014 \\
\hline
\end{tabular}

$p_{\mathrm{O}_{2}}=10^{-15} \mathrm{~atm},\left[V_{\mathrm{O}}^{* *}\right]=5$ and $10 \%$.

The ionic radii are those given by Shannon ${ }^{22}$ for a coordination number of 8 .

${ }^{\mathrm{b}} \Delta r=\left|r_{\text {dopant }}-r_{\mathrm{c}}\right|$, see text.

centration seems to be a function of the oxygen partial pressure only. This is valid for oxide vacancy concentrations at least up to $10 \%$ of the oxide sites irrespective of whether the dopant is $\mathrm{Gd}^{3+}$ or $\mathrm{Ce}^{3+}$. If it is assumed that this is also valid if $\mathrm{Ca}$ is the dopant then, according to Eq. 1, the electron concentration, $n$, should be the same for the same $y$-value in Fig. 12. The electronic mobility is defined by

$$
\sigma_{\mathrm{e}}=n e \mu_{\mathrm{e}}
$$

where $e$ is the elementary charge, and $\mu_{\mathrm{e}}$ the electron mobility. In Fig. $12 \sigma_{\mathrm{e}}$ is considerably higher for the samples doped with $\mathrm{CaO}$. This implies that it is not the extent of the reduction which alone determines $\sigma_{\mathrm{e}}$. If the electron concentration, $n$, is assumed to be equal for $\mathrm{Ce}_{0.8} \mathrm{Gd}_{0.2} \mathrm{O}_{1.9}$ and $\mathrm{Ce}_{0.9} \mathrm{Ca}_{0.1} \mathrm{O}_{1.9}$ at $p_{\mathrm{O}_{2}}=10^{-15}$ atm then the only explanation for the difference in $\sigma_{e}$ is a considerable variation in the electron mobility. The electron mobility in small polaron conductors is described by Tuller and Nowick ${ }^{25}$ as having the following form

$$
\mu_{e}=\left(\frac{\left[\mathrm{Ce}_{\mathrm{Ce}}^{x}\right] e a^{2} v_{0}}{k T}\right) \cdot \exp \left(\frac{-E_{\mathrm{H}}}{k T}\right)
$$

where $a$ is the jump distance, $v_{0}$ the attempt frequency, $E_{\mathrm{H}}$ the hopping energy, and $k$ is the Boltzmann constant.

An important variable in the mobility is $\left[\mathrm{Ce}_{\mathrm{C}}^{\mathrm{x}}\right]$, i.e., the concentration of sites where the electron can jump. If some $\mathrm{Ce}_{\mathrm{Ce}}^{x}$ sites are exchanged with a fixed valence ion like $\mathrm{Gd}_{\mathrm{Ce}}^{\prime}$ or $\mathrm{Ca}_{\mathrm{Ce}}$ fewer sites are available for the mobile electrons, thereby reducing the mobility and hence $\sigma_{\mathrm{e}}$.

For the samples compared in Fig. $12\left[\mathrm{Ca}_{\mathrm{Ce}}^{\prime \prime}\right]$ is only half the value of $\left[\mathrm{Gd}_{\mathrm{Ce}}^{\prime}\right]$ which partly explains the difference in $\sigma_{\mathrm{e}}$. In Fig. $13 \sigma_{\mathrm{e}}$ is compared for equal concentrations of dopant metal ions. In this case the two curves appear almost merging with a tendency toward $\mathrm{CaO}$ giving a higher value of $\sigma_{\mathrm{e}}$

Were $\sigma_{\mathrm{e}}$ controlled solely by $\left[V_{0}^{* *}\right.$ ] and dopant metal ion concentration, the samples doped with $\mathrm{Gd}_{2} \mathrm{O}_{3}$ would have exhibited the highest conductivity in Fig. 13. Apparently other parameters have a determining influence on $\sigma_{e}$ with the consequence that calcia-doped samples obtain a higher $\sigma_{\mathrm{e}}$ than gadolinia doped. This may be because the vacancydopant associates in the $\mathrm{Ca}$ case $\left(\mathrm{Ca}_{\mathrm{Ce}}^{\prime \prime}-V_{\mathrm{O}}^{* *}\right)$ are neutral while in the $\mathrm{Gd}$ case $\left(\mathrm{Gd}_{\mathrm{Ce}}^{\prime}-V_{\mathrm{o}}^{\prime}\right)$ they are positively charged and this may decrease the electron mobility.

Table I compares $\sigma_{\mathrm{e}}$ at $p_{\mathrm{O}_{2}}=10^{-15}$ atm with the ionic radii of different dopants. Again as in Fig. 8 and 12 compounds with the same nominal vacancy concentration are compared. The values indicate that the ionic radii do not influence the size of $\sigma_{e}$.

Dimensional changes.- When $\mathrm{Ce}^{4+}$ is reduced to $\mathrm{Ce}^{3+}$ the lattice of $\mathrm{CeO}_{2}$ expands because the ion radius of $\mathrm{Ce}^{3+}$ is considerably larger than the radius of $\mathrm{Ce}^{4+}$. At room temperature the expansion can be calculated from XRD data as compiled by $\mathrm{Kim}^{21}$ and Shannon. ${ }^{22}$ At high temperature such XRD data are not available and therefore the expansion was measured by isothermal dilatometry. Figure 14 shows the relative expansion as a function of $p_{\mathrm{O}_{2}}$ at $1000^{\circ} \mathrm{C}$

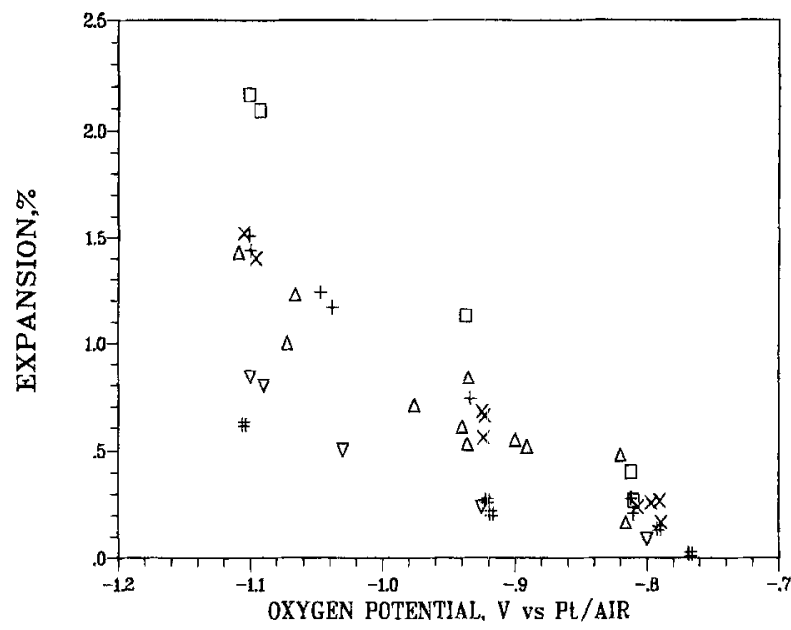

Fig. 14. Relative expansion as a function of oxygen potential, $\square$ pure $\mathrm{CeO}_{2}, \times 20 \% \mathrm{Gd}, \nabla 40 \% \mathrm{Gd}, \# 50 \% \mathrm{Er},+10 \% \mathrm{Ca}, \triangle 20 \% \mathrm{Ca}$, all at $1000^{\circ} \mathrm{C}$.

for pure and 5 doped cerias. The clear trend is that the higher the degree of doping with two- or three-valent cations, the less the relative expansion associated with the reduction of the samples. This is in agreement with the equilibria given by Eq. 1 and 2 .

A considerable scatter is seen in $20 \%$ Ca in Fig. 14. A possible explanation may be that this composition is not stable in reduced condition over periods of time of 20 to 40 $\mathrm{h}$, i.e., some of the $\mathrm{Ca}$ is "precipitated" in domains with some extra ordering of $\mathrm{Ca}_{\mathrm{Ce}}^{\prime \prime}$ and $V_{\mathrm{O}}^{* *}$ as compared to the oxidized state. This implies that the actual expansion is dependent on the hold time at a given condition. This is being investigated further. Figure 14 also reveals that even in case of as high a degree of doping as $40 \% \mathrm{Gd}$ or $50 \% \mathrm{Er}$ there is still an appreciable expansion below $-1 \mathrm{~V}$.

The thermal expansion coefficients (TEC) of the samples in Fig. 14 are given in Table II. The ceria TECs are in all cases higher than for yttria-stabilized zirconia (YSZ).

Extent of matching of the SOFC anode requirements.The experimental results show that the requirement of an ionic conductivity of $\sigma_{i} \geq 0.1 \mathrm{~S} / \mathrm{cm}$ is easily met. Otherwise with the electronic conductivity. Irrespective of which kind and degree of dopant, $\sigma_{e} \geq 100 \mathrm{~S} / \mathrm{cm}$ never can be met for ceria-based material. So to use ceria as an anode a current collector with the required electronic conductivity must be implemented. A possible candidate for this may be porous chromium steel of a composition similar to the metallic SOFC interconnector plate reported by Drenckhahn and Vollmar. $^{33}$

The results (Fig. 14) show that we must substitute about half the Ce atoms with Gd or similar rare-earth element to obtain a reasonable dimensional stability. In doping with $\mathrm{Ca}$ there may be a problem with both dimensional and thermodynamic stability. It is probably not possible to avoid an expansion of at least $0.3 \%$. Whether this is allow-

Table II. TEC for various doped cerias in air in the interval 50 to $1000^{\circ} \mathrm{C}$.

Composition

TEC

$\left(10^{-6} \mathrm{~K}^{-1}\right)$

$\begin{array}{cc}\mathrm{CeO}_{2} & 12.3 \\ \mathrm{Ce}_{0.8} \mathrm{Gd}_{0.2} \mathrm{O}_{1.9} & 12.5 \\ \mathrm{Ce}_{06} \mathrm{Gd}_{0.4} \mathrm{O}_{1.8} & 12.1 \\ \mathrm{Ce}_{05} \mathrm{Er}_{0.5} \mathrm{O}_{1.75} & 11.4 \\ \mathrm{Ce}_{0.9} \mathrm{Ca}_{0.1} \mathrm{O}_{1.9} & 12.8 \\ \mathrm{Ce}_{0.8} \mathrm{Ca}_{0.2} \mathrm{O}_{1.8} & 13.6 \\ \mathrm{Zr}_{0.85} \mathrm{Y}_{0.15} \mathrm{O}_{1.925} & 10.8\end{array}$

TEC for the most widely used yttria-stabilized zirconia measured with the same dilatometer is given for comparison. 
able or not probably depends on the actual structure of the full cell stack.

The TEC match with YSZ is believed to be acceptable at least for the heavily Gd- and Er-doped cerias.

The chemical compatibility of $\mathrm{CeO}_{2}$ with $\mathrm{YSZ}$ is not without problems as the two materials diffuse into each other at the sintering temperature which typically is about $1300^{\circ} \mathrm{C}$ or above. The $\mathrm{CeO}_{2}-\mathrm{YSZ}$ solutions have considerably lower oxide ion conductivities than YSZ itself. At $1000^{\circ} \mathrm{CZr}_{085} \mathrm{Y}_{0.15} \mathrm{O}_{1.925}$ has a stable ion conductivity of about $0.12 \mathrm{~S} / \mathrm{cm}$ while for YSZ mixed with various amounts of $\mathrm{Ce}^{4+}$ and $\mathrm{Gd}^{3+}$ was in the range of 0.02 to $0.06 \mathrm{~S} / \mathrm{cm} .{ }^{34}$ The same trend is seen in the work of Cales and Baumard. ${ }^{35}$ This means that during the fabrication process measures should be taken to avoid the interdiffusion, e.g., by using low temperature methods or by applying a suitable diffusion barrier onto the YSZ surface. ${ }^{36}$

The requirement of high electrocatalytic activity seems to be fulfilled for oxidation of hydrogen, ${ }^{1.2}$ but still more work is needed to see if it can be made high enough for direct $\mathrm{CH}_{4}$ oxidation.

\section{Conclusion}

For $\mathrm{CeO}_{2}$-based anodes it seems that the best composition is one where 40 to $50 \%$ of the $\mathrm{Ce}^{4+}$ is substituted with three-valent rare-earth cations like $\mathrm{Y}^{3+}, \mathrm{Gd}^{3+}$, or similar rare-earth cation with slightly smaller ion radius.

\section{Acknowledgment}

This work was carried out as part of the joint Danish SOFC program which is sponsored by the Danish Energy Agency and the Danish electric utilities ELSAM and ELKRAFT. The assistance from many members of the SOFC group at Risø and Haldor Topsøe A/S is gratefully acknowledged.

Manuscript submitted Feb. 23, 1993; revised manuscript received March 28, 1994. This was Paper 682 presented at the San Francisco, CA, Meeting of the Society, May 22-27, 1994.

Risø National Laboratory assisted in meeting the publication costs of this article.

\section{REFERENCES}

1. M. Mogensen and J. J. Bentzen, in Proceedings of the First International Symposium on Solid Oxide Fuel Cells, S. C. Singhal, Editor, PV 89-11, p. 99, The Electrochemical Society Proceedings Series, Pennington, NJ (1989).

2. M. Mogensen, B. Kindl, and B. Malmgren-Hansen, in Program and Abstracts of 1990 Fuel Cell Seminar, Nov. 25-28, 1990, Phoenix, AZ, pp. 195-198.

3. B. C. H. Steele, P. H. Middleton, and R. A. Rudkin, Solid State Ionics, 40/41, 388 (1990).

4. G. Mogensen and M. Mogensen, Thermochim. Acta, 214, 47 (1993).

5. D. Y. Wang, D. S. Park, J. Griffith, and A. S. Nowick, Solid State Ionics, 2, 95 (1981).

6. R. Gerhardt and A. S. Nowick, J. Am. Ceram. Soc., 69, 641 (1986).

7. H. Yahiro, T. Ohuchi, and K. Eguchi, J. Mater. Sci., 23, $1036(1988)$
8. T. Kudo and H. Obayashi, This Journal, 123, 415 (1976).

9. D. Y. Wang and A. S. Nowick, J. Solid State Chem., 35, 325 (1980).

10. T. Ivers-Tiffée and D. Küstner, Silicates Industriels, 1112, 227 (1984).

11. M. P. Pechini, U.S. Pat. 3,330,697 (1967).

12. F. S. Brugner and R. N. Blumenthal, J. Am. Ceram. Soc., 54, 57 (1971).

13. J. J. Bentzen, N. H. Andersen, F. W. Poulsen, O. T. Sørensen, and R. Schram, Solid State Ionics, 28-30, 550 (1988).

14. J. R. Macdonald, Complex Nonlinear Least Squares Immitance Fitting Program, version 8/16/90. University of North Carolina, Chapel Hill.

15. J. A. Kilner and B. C. H. Steele, in Nonstoichiometric Oxides, O. T. Sørensen, Editor, p. 233, Academic Press, New York (1981).

16. H. Obayashi and T. Kudo, in Solid State Chemistry of Energy Conversion and Storage, J. B. Goodenough and M. S. Wittingham, Editors, Advances in Chemistry Series 163, American Chemical Society, Washington, DC (1977).

17. D. K. Hohnke, Solid State Ionics, 5, 531 (1981).

18. P. Duran, J. R. Jurado, C. Pascual, J. M. Rodriguez, and C. Moure, Mater. Sci. Monogr, 38B, 1943 (1987).

19. R. N. Blumenthal, F. S. Brugner, and J. E. Garnier, This Journal, 120, 1230 (1973).

20. H. Arai, T. Kunisaki, Y. Shimizu, and T. Seiyama, Solid State Ionics, 20, 251 (1986).

21. D. J. Kim, J. Am. Ceram. Soc., 72, 1415 (1989).

22. R. D. Shannon, Acta Cryst., A32, 751 (1976).

23. B. Zachau-Christiansen, T. Jacobsen, K. West, and S. Skaarup, in Proceedings of the Third International Symposium on Solid Oxide Fuel Cells, S. C. Singhal and $\mathrm{H}$. Iwahara, Editors, PV 93-4, p. 104, The Electrochemical Society Proceedings Series, Pennington, NJ (1993).

24. T. Jacobsen, B. Zachau-Christiansen, $K$. West, and $\mathrm{S}$. Skaarup, in Proceedings of the Second International Symposium on Solid Oxide Fuel Cells, p. 795, Report EUR 13564EN (1991).

25. H. L. Tuller and A. S. Nowick, J. Phys. Chem. Solids, 38, 859 (1977)

26. H. L. Tuller and A. S. Nowick, This Journal, 126, 209 (1979).

27. I. K. Naik and T. Y. Tien, J. Phys. Chem. Solids, 39, 311 (1978).

28. T. Ivers-Tiffée and H. J. Oel, in High Tech Ceramics, P. Vincenzini, Editor, p. 1933, Elsevier Science Publishers b.V., Amsterdam (1987).

29. K. L. El Adham, Ph.D. Thesis, University of Grenoble, Grenoble, France.

30. I. K. Naik and T. Y. Tien, This Journal, 126, 563 (1979).

31. W. R. Hosler and H. P. R. Frederikse, in Sixth International Conference on MHD Power Generation, CONF 750601-P2, p. 67 (1975).

32. R. N. Blumenthal and J. E. Garnier, J. Solid State Chem., 16, 21 (1976).

33. W. Drenckhahn and H.-E. Vollmar, in Program and $\mathrm{Ab}$ stract of 1992 Fuel Cell Seminar, Nov. 29 to Dec. 2, 1992, Tucson, AZ, p. 419.

34. J. J. Bentzen and H. Schwartzbach, Solid State Ionics, 40/41, 942 (1990).

35. B. Cales and J. F. Boumard, This Joumal, 131, 2407 (1984).

36. M. Mogensen and B. Kindl, Danish Pat. 167.163. 